JURNAL

MANAJEMEN PENDIDIKAN

Vol. 5 No.2 Maret 2021: pp.67-73

PENELITIAN KUALITATIF

e-ISSN: 2775-6904 | p-ISSN: 2502-9487

RESEARCH ARTICLE

OPEN ACCESS

\title{
MANAJEMEN PROGRAM PENDIDIKAN DI TVRI RIAU DAN KEPRI (Tinjauan Berdasarkan Fungsi Manajemen)
}

\author{
Debi Ramona ${ }^{1}$ \\ Isjoni $^{2}$ \\ Azhar $^{3}$ \\ ${ }^{1,2,3}$ Magister Administrasi Pendidikan Pascasarjana Universitas Riau
}

\begin{abstract}
This study aims to explain the management functions of educational programs on TVRI Riau \& Riau Islands Station. This type of research is qualitative research. The data type of this research is using primary data. Research data was obtained from the head of the program and business development section, head of the program subsection, and all staff of TVRI Riau \& Riau Islands. The instrument of this research is the researchers themselves by applying interview guides, observation checklists, and documentation. Data analysis techniques are field analysis and results analysis, process results by (1) data reduction, (2) data presentation, (3) conclusion drawing. The results of this study indicate that the management of education programs at Tvri Riau \& Riau Islands stations have met television management standards, starting from complete facilities, adequate human resources despite the limited number of human resources, having a structured organizational structure.
\end{abstract}

Key words: management; educational programs; TVRI Riau; Riau Islands Station

\begin{abstract}
Abstrak: Penelitian ini bertujuan untuk menjelaskan fungsi manajemen program pendidikan di TVRI Stasiun Riau \& Kepri. Jenis penelitian adalah penelitian kualitatif. Data penelitian menggunakan data primer. Data penelitian diperoleh dari kepala seksi program dan pengembangan usaha, kepala sub seksi program, dan staf TVRI Riau \& Kepri. Teknik pengumpulan data adalah wawancara, observasi dan dokumentasi. Instrumen penelitian ini adalah peneliti sendiri dengan menerapkan panduan wawancara, daftar periksa observasi, dan dokumentasi. Teknik analisis data yaitu analisis lapangan dan analisis hasil dengan proses (1) reduksi data, (2) penyajian data, (3) penarikan kesimpulan. Hasil penelitian ini menunjukkan bahwa manajemen program pendidikan di Tvri Stasiun Riau \&Kepri sudah memenuhi standar manajemen televisi, dimulai dari fasilitas yang sudah lengkap, sumber daya manusia yang memadai meskipun masih terdapat keterbatasan jumlah sumber daya manusia, memiliki struktur organisasi yang terstruktur.
\end{abstract}

Kata Kunci: Manajemen; Program Pendidikan; TVRI Riau; Stasiun Riau Kepulauan

\section{PENDAHULUAN}

Perkembangan ilmu pengetahuan dan teknologi menuntut masyarakat untuk mampu mengikuti perkembangan yang ada. Peran ilmu pengetahuan dan teknologi bermanfaat bagi setiap masyarakat untuk mendapatkan berbagai kemudahan dan informasi yang dapat digunakan dalam kehidupan seharihari. Pendidikan merupakan salah satu wadah strategis bagi masyarakat untuk memperoleh ilmu pengetahuan dan mengikuti perkembangan teknologi yang ada guna meningkatkan pengetahuannya. Dalam Undang-Undang No. 20 tahun 2003 menjelaskan pendidikan adalah usaha sadar dan terencana untuk mewujudkan suasana belajar dan proses pembelajaran peserta didik secara aktif mengembangkan potensi dirinya untuk memiliki kekuatan spiritual keagamaan, pengendalian diri, kepribadian, kecerdasan, akhlak mulia, serta keterampilan yang diperlukan dirinya dan masyarakat. 
JURNAL

MANAJEMEN PENDDIKAN Vol. 5 No.2 Maret 2021: pp.67-73

PENELITIAN KUALITATIF

Pendidikan tidak sebatas pengetahuan yang didapatkan melalui jalur pendidikan formal semata, melainkan pendidikan juga bisa didapatkan melalui informasi yang dimuat dalam program acara pendidikan yang disiarkan melalui program televisi. Televisi telah menjadi bagian yang tak terpisahkan dari kehidupan sehari-hari masyarakat. Televisi menyita perhatian dan menjadi primadona dalam setiap lapisan masyarakat. Hal tersebut sesuai dengan pernyataan Gerbner dan Conolly dalam Ashadi Siregar yang menyebutkan bahwa televisi menyita waktu yang lebih banyak serta perhatian dari lebih banyak orang dibandingkan dengan media lainnya sehingga muncul istilah "Television as New Religion". Televisi merupakan sarana hiburan yang murah dan dekat karena disajikan di ruang-ruang keluarga kita (Ashadi Siregar, 2001:2).

Teknologi televisi masuk di Indonesia pada tahun 1962 yang ditandai dengan munculnya stasiun televisi pertama yaitu Televisi Republik Indonesia (TVRI). Lahirnya TVRI diawali dengan siaran percobaan berupa siaran langsung upacara peringatan hari proklamasi kemerdekaan Indonesia ke-17, pada tanggal 17 Agustus 1962. Seminggu kemudian, tepatnya tanggal 24 Agustus 1962, TVRI sudah melaksanakan siaran resmi yaitu siaran langsung upacara pembukaan Asian Games ke-4 dari stadion utama Gelora Bung Karno, Jakarta.Melalui proses yang panjang, TVRI telah memperluas jaringannya dalam bidang informasi yaitu dengan didirikannya TVRI di setiap provinsi di Indonesia. Hal tersebut bertujuan untuk mengangkat informasi-informasi yang terjadi di daerah serta menayangkan setiap kearifan lokal dari masing-masing daerah tersebut.

Salah satu stasiun yang didirikan di setiap provinsi adalah TVRI Stasiun Riau \& Kepri yang diresmikan pada tanggal 03 november 1998 oleh Menteri Penerangan. Pada masa itu, TVRI Stasiun Riau \& Kepri masih berstatus sebagai stasiun produksi karena belum mampu melakukan siaran sendiri dan hanya memproduksi program acara dokumenter yang dikirim dan disiarkan melalui TVRI pusat di Jakarta. Pada bulan Januari tahun 1999 TVRI stasiun Riau \& Kepri melakukan siaran lokal perdana selama satu jam, dari sinilah TVRI stasiun Riau\& Kepri terus berkembang dan berupaya meningkatkan jam siaran serta jangkauan siarannya, saat ini TVRI stasiun Riau \& Kepri telah mampu melaksanakan siaran selama empat jam setiap harinya dan memiliki daya jangkauan siaran yang cukup luas hingga sampai ke wilayah kepulauan Riau (Dokumen Selayang Pandang LPP TVRI Stasiun Riau \& Kepri, 2012). Beragam program acara yang ada di stasiun TVRI Riau \& Kepri tersebut merupakan hasil dari sumber daya manusia yang ada dalam manajemen TVRI Stasiun Riau \& Kepri. Dimana salah satu as pek dalam membuat sebuah program acara yang memuat nilai-nilai pendidikan dalam pertelevisian adalah manajemen yang baik. Manajemen merupakan sebuah proses perencanaan (planning), pengorganisasian (organizing), pengkoordinasian (leading), dan pengontrolan (controlling) sumber daya untuk mencapai tujuan secara efektif dan efisien (Morissan, 2008:130). Manajemen dibutuhkan oleh semua organisasi, tak terkecuali oleh sebuah institusi media. Tujuan manajemen dalam suatu organisasi guna mencapai tujuan bersama yaitu berdasarkan pedoman yang sama dalam mencapai tujuan organisasi. Tujuan dapat dicapai, jika dalam proses pengarahan manajemennya dapat membangkitkan dan meningkatkan sumber daya manusianya sebagai aktivitas dan kekuatan hakiki suatu organisasi. Pentingnya Manajemen Produksi bagi sebuah program pendidikan, dimana manajemen sebagai proses yang menggerakkan organisasi karena tanpa manajemen yang efektif maka di dalam organisasi tidak akan ada usaha yang akan berhasil.

Untuk memperjelas serta memberi arahan yang tepat dalam pembahasan ini, maka penulis membatasi permasalahan sebagai berikut:

1. Bagaimana perencanaan manajemen program pendidikan di TVRI Stasiun Riau \& Kepri tinjauan berdasarkan fungsi manajemen?

2. Bagaimanakah pengorganisasian manajemen program pendidikan di TVRI Stasiun Riau \& Kepri tinjauan berdasarkan fungsi manajemen?

3. Bagaimanakah pengkoordinasian manajemen program pendidikan di TVRI Stasiun Riau \& Kepri tinjauan berdasarkan fungsi manajemen?

4. Bagaimanakah pengawasan manajemen program pendidikan di TVRI Stasiun Riau \& Kepri tinjauan berdasarkan fungsi manajemen?

5. Adakah faktor pendukung dan penghambat dalam pelaksanaan manajemen program pendidikan di TVRI Stasiun Riau \& Kepri tinjauan berdasarkan fungsi manajemen? 


\section{METODOLOGI PENELITIAN}

\section{Metode Penelitian}

Jenis penelitian yang dilakukan dalam penelitian ini adalah kualitatif yang menghasilkan data deskriptif yaitu memberikan gambaran tentang Manajemen Program Pendidikan di TVRI Stasiun Riau \& Kepri (Tinjauan berdasarkan fungsi manajemen). Sehubungan dengan itu Penelitian kulalitatif adalah penelitian yang menghasilkan data deskriptif (Maleong, 1989:112).

\section{Tempat dan Waktu Penelitian}

Penelitian ini dilaksanakan di Lembaga Penyiaran Publik TVRI stasiun Riau \& Kepri jalan Durian no. 24 Kelurahan Labuhbaru Pekanbaru Riau. Penelitian akan dilaksanakan pada bulan Maret 2017 sampai bulan Juni 2017.

\section{Informan Penelitian}

Data dalam penelitian ini, diperoleh dari informan penelitian yang terdiri dari tiga orang informan dengan alasan latar belakang jabatan dan tugas dalam manajemen di TVRI stasiun Riau \& Kepri, pendidikan, juga umur. Informan tersebut yaitu: Kepala Seksi Program dan Pengembangan Usaha (Produser), Kepala sub seksi program (Produser Pelaksana ), Staf Program (Pengarah Acara)

\section{Teknik Pengumpulan Data}

Dalam penelitian ini untuk mengumpulkan data penulis akan menggunakan alat sebagai berikut : wawancara, Observasi, dan Dokumentasi.

\section{Analisis Data}

Dalam penelitian ini analisis data yang digunakan yaitu semua yang terjadi, baik yang direncanakan maupun tidak direncanakan perlu dianalisis untuk melihat bagaimana pengelolaan manajemen pendidikan khususnya dalam hal perencanaan, pengorganisasian, pelaksanaan. Data yang dikumpulkan melalui observasi dan wawancara akan dianalisis melalui dua tahap yaitu Analisis Lapangan : dilakukan oleh peneliti saat pengamatan dan proses pengambilan data. Analisi lapangan memungkinkan penyederhanaan berupa catatan pertanyaan yang diajukan pada subjek penelitian. Analisis Hasil Dilakukan setelah data terkumpul. Analisis hasil dilakukan dalam tahap-tahap berikut yaitu: (1) reduksi data, (2) penyajian data, (3) penarikan kesimpulan (Miles dan Huberman, 1992 : 16).

\section{Keabsahan Data}

Untuk menjaga keabsahan pada penelitian ini, penulis melakukan observasi dan wawancara serta studi dokumentasi. Diharapkan dengan melakukan beberapa kegiatan tersebut data yang diperoleh dapat terjaga keabsahannya. Ada empat kriteria yang digunakan yaiu, perpanjangan pengamatan, peningkatan ketekunan, triangulasi dan pengujian keabsahan data.

\section{HASIL DAN PEMBAHASAN}

\section{Sejarah dan Profil TVRI Stasiun Riau \& Kepri}

Pada tahun 1964 TVRI mulai merintis pembangunan Stasiun Penyiaran Daerah, dimulai dengan TVRI Stasiun Yogyakarta, yang secara berturut-berturut diikuti dengan dibangunnya Stasiun Medan, Surabaya, Ujungpandang (Makassar), Manado, Denpasar dan Balikpapan (Bantuan Pertamina) dan diikuti oleh beberapa daerah lainnya yang tersebar diseluruh Indonesia

Dari beberapa stasiun TVRI daerah yang tersebar di seluruh Indonesia, salah satunya adalah TVRI stasiun Riau \& Kepri. Tvri Riau \& Kepri diresmikan pada tanggal 03 November tahun 1998. Sama halnya dengan kebanyakan stasiun daerah TVRI lainnya, yang menyiarkan tayangan program hiburan, program informasi, program budaya, program berita. Selain itu TVRI stasiun Riau \& Kepri juga menayangkan beberapa program yang mengandung unsur yang bertema program pendidikan dan juga beberapa tayangan dengan tema lainnya. 
JURNAL

MANAJEMEN PENDIDIKAN

PENELITIAN KUALITATIF
Vol. 5 No.2 Maret 2021: pp.67-73

e-ISSN: 2775-6904 | p-ISSN: 2502-9487

Visi dan Misi TVRI Stasiun Riau \& Kepri

1) Visi TVRI Stasiun Riau \& Kepri

Adapun visi TVRI Stasiun Riau \& Kepri adalah: "Terwujudnya LPP TVRI Stasiun Riau Kepri sebagai media utama penggerak , pembangunan di Propinsi Riau dan Propinsi Kepulauan Riau".

2) MisiTVRI Stasiun Riau \& Kepri

1. Menyelenggarakan Program Siaran yang menumbuhkan rasa cinta tanah air.

2. Menyelenggarakan siaran yang mendidik, menghibur, serta memberi pelayanan informasi yang sehat dan berimbang, dalam membangun budaya daerah dan sebagai kontrol sosial.

3. Menyelenggarakan tata kelola lembaga yang mengacu pada lembaga penyiaran yang moderen.

\section{Manajemen Program Pendidikan di TVRI Stasiun Riau \& Kepri}

Langkah-langkah proses produksi program tv yaitu: praproduksi, produksi dan pasca produksi. Sedangkan fungsi manajemen yang dijalankan adalah:

\section{Planning}

Planning atau perencanaan merupakan tahapan awal yang sangat menentukan keberhasilan proses selanjutnya. Perencanaan disini mencakup rapat redaksi, menyusun pola acara, materi, menentukan ide dan topik utama, menyusun rundown, menentukan kru atau sumber daya yang akan dilibatkan, menghitung alokasi dana yang dibutuhkan, menentukan waktu pelaksanaan, peralatan yang akan digunakan serta pengisi acara yang akan dilibatkan dalam produksi nantinya. Fungsi perencanaan ini diterapkan dalam manajemen program pendidikan di TVRI Stasiun Riau \& Kepri ini dilakukan setiap akan memproduksi program yang dilakukan.

\section{Organizing}

Organizing atau pengorganisasian merupakan penentuan siapa-siapa saja yang akan dilibatkan dalam manajemen pendidikan di TVRI Stasiun Riau \& Kepri dalam memproduksi program pendidikan. Pengorganisasian mencakup kegiatan pembagian kerja kedalam bidang-bidang khusus dan pengelompokan karyawan dengan tanggung jawab tertentu kedalam kegiatan manajemen. Penerapan fungsi pengorganisasian dalam manajemen TVRI stasiun Riau \& Kepri sudah mengacu pada aspek aspek penggorganisasian dalam fungsi manajemen walaupun terkadang mengalami kendala yang dikarenakan terbatasnya sumber daya manusia (SDM) yang berkualitas yaitu memiliki kreativitas tinggi dan kedisiplinan. Namun demikian hal tersebut masih bisa ditangani dengan baik oleh kerjasama. Sehingga manajemen dapat berjalan dengan baik dan lancar sesuai dengan fungsinya.

\section{Leading}

Pengkoordinasian memiliki tujuan-tujuan yang mendasar dalam memberikan pengarahan bagi staf yang terlibat dalam manajemen program pendidikan di TVRI Stasiun Riau \& Kepri, tujuan yang dimaksud ialah sebagai berikut: menciptakan lingkungan dan suasana kerja yang kondusif, para staf yang terlibat dalam tim manajemen melaksanakan tugasnya secara efektif dan efisien, tim manajemen memilki tanggung jawab terhadap tugas-tugas yang diembannya, tim manajemen memiliki kedisiplinan dalam menjlankan tugasnya, menciptakan komunikasi yang baik baik anatar produser selaku pimpinan dan kru selaku bawahan maupun antara sesama kru, menghindari adanya celah yang dapat menggangu kualitas kerja dan kelancaran produksi, mengingat pekerjaan yang dilakukan adalah pekerjaan tim, mendorong semangat kerja dan memotivasi seluruh tim.

\section{Controlling}

Keseluruhan fungsi manajemen diatas tidak akan berjalan secara efektif tanpa adanya fungsi controlling atau pengawasan. fungsi controlling di TVRI stasiun Riau \& Kepri berjalan sesuai dengan aspek aspek pengawasan dalam fungsi manajemen, produser disini selalu melakukan evaluasi rutin dengan bertujuan mengukur sejauh mana keberhasilan dari rencana program yang telah dijalankan. Adapun kegiatan yang dilakukan oleh manajemen TVRI Riau \& Kepri dalam fungsi ini yaitu:

1) Melakukan penilaian terhadap hasil siaran 


\section{JURNAL}

\section{MANAJEMEN PENDDIKAN Vol. 5 No.2 Maret 2021: pp.67-73

PENELITIAN KUALITATIF

2) Memastikan apakah hasil siaran sesuai dengan tujuan awal yang ditetapkan dalam perencanaan awal

3) Memastikan setiap kru/ sumber daya yang terlibat telah melaksanakan tugas sesuai dengan yang ditelah dibagi dalam pengorganisasian

4) Melakukan evaluasi hal - hal apa saja yang perlu diperbaiki agar kesalahan yang sama tidak terulang dalam produksi program pendidikan selanjutnya.

Faktor Pendukung dan Penghambat manajemen program pendidikan di TVRI Stasiun Riau \& Kepri

Faktor-faktor pendukung tersebut diantanya adalah Peralatan yang memadai, sejauh ini di TVRI Stasiun Riau \& Kepri peralatan yang menjadi sarana dan prasarana sudah sangat memadai untuk mendukung pembuatan program pendidikan. Faktor pendukung lain yaitu budgeting yang pas. Hal lain yang menjadi kelebihan dan faktor pendukung dalam manajemen program pendidikan di TVRI Stasiun Riau \& Kepri dari ketersediaan sumber daya manusia yang produktif, dimana hampir $65 \%$ tenaga operasionalnya merupakan tenaga-tenaga yang berusia dibawah 30 tahun.

Sedangkan faktor penghambat antara lain terbatasnya sumber daya manusia (SDM) di TVRI Stasiun Riau \& Kepri, karena ketersedian sumber daya manusia merupakan hal terpenting dalam untuk menjalankan sebuah manajemen, selanjutnya factor alam juga menjadi penghambat, dan factor penghambat lain adalah keterbatasan waktu untuk membuat program acara yang berkualitas.

Dari berbagai kelemahan yang ada manajemen program pendidikan di TVRI melakukan beberapa hal untuk meminimalisir kendala yang ada, sehingga hal-hal tersebut tidak lagi menjadi penghambat. untuk permasalahan sumber daya manusia yang terbatas solusinya adalah, dari segi kualitas manajemen memberikan pelatihan bagi staf yang kurang berkopeten dengan mengikut diklat (pendidikan dan pelatihan). Sedangkan dari segi jumlah manjemen berupaya memanfaatkan apa yang ada semaksimal mungkin.Untuk permasalahan faktor alam, TVRI Stasiun Riau \& Kepri melakukan siaran yang dikembalikan ke siaran TVRI nasional, sehingga tidak terjadi kekosongan siaran pada saat itu. Sedangkan untuk program live yang sedang berjalan dilakukan rekaman dan akan ditayangkan kembali saat ada waktu yang tepat sehingga kehadiran narasumber tidak sia-sia dan program dapat terus berlanjut.

Sedangkan untuk masalah keterbatasan sumber daya manusia dan waktu untuk memproduksi sebuah program acara yang memiliki beberapa tahapan dan menyita waktu, manajemen merangkul pihak ketiga diluar TVRI Stasiun Riau \& Kepri untuk menjalankan program ini, sehingga yang diperoleh oleh TVRI hanya penampilan yang jadi dan siap tayang. Tentunya ini sangat memberikan kemudahan bagi manjemen untuk menjalankan program pendidikan tersebut.

Di balik kesuksesan suatu program hasil produksi manajemen pada stasiun televisi terdapat manajemen yang baik di belakangnya, ada tiga alasan utama yang menempatkan manajemen dalam posisi penting, yaitu :

a. Manajemen diperlukan untuk mencapai tujuan, hal ini berarti bahwa manajemen dilakukan dalam rangka pencapaian tujuan organisasi.

b. Manajemen dibutuhkan untuk menjaga keseimbangan. Ini berarti bahwa manajemen diperlukan untuk menjaga keseimbangan antara tujuan-tujuan, sasaran-sasaran dan kegiatan-kegiatan yang saling bertentangan dari pihak-pihak yang berkepentingan dalam organisasi.

c. Manajemen diperlukan dalam rangka mencapai efisiensi dan efektifitas. Suatu kerja organisasi dapat diukur dengan banyak cara yang berbeda, salah satu cara yang umum yang banyak digunakan adalah dengan menggunakan patokan efisiensi dan efektivitas.

\section{SIMPULAN}

Berdasarkan hasil temuan penelitian, analisis serta pembahasan yang telah dilakukan, maka dapat disimpulkan bahwa suatu organisasi televisi selalu ingin mempertahankan eksistensi dalam penyajian program-program yang berkualitas. Pelaksanaan manajemen mengindikasi bahwa manajemen bisa dilihat dalam aspek berikut ini. Manajemen berkaitan dengan proses, hal ini berarti bahwa manajemen bukan tindakan yang bersifat tunggal, namun serangkaian tindakan yang tertata dalam alur proses 
JURNAL

MANAJEMEN PENDIDIKAN Vol. 5 No.2 Maret 2021: pp.67-73

PENELITIAN KUALITATIF

e-ISSN: 2775-6904 | p-ISSN: 2502-9487

tertentu yang telah direncanakan sebelumnya. Kedua, manajemen melibatkan aspek sumber daya manusia dan materi. Ini berarti bahwa dalam manajemen melibatkan orang lain, bukan merupakan tindakan yang dilakukan oleh satu orang saja, namun tindakan yang dilakukan oleh beberapa orang. Ketiga, manajemen diarahkan untuk mencapai tujuan bersama dari organisasi. Ini berarti bahwa dalam manajemen, selalu ada perencanaan yang dilakukan sebelum pelaksanaan dilakukan. Ketika pelaksanaan sudah dilakukan, kontrol pengawasan atas pelaksanaan dilakukan dengan maksud agar arah untuk mencapai tujuan bersama dapat tercapai. Terakhir, manajemen berkaitan dengan fungsi-fungsi manajemen.Pentingnya manajemen pada suatu program selalu dikaitkan dengan fungsi dari manajemen itu sendiri, yaitu : Planning, Organizing, Leading dan Controlling, dimana dalam proses kerja yang demikian rumit sangat memerlukan suatu pengaturan atau manajemen yang baik dalam proses kerja program tersebut.

Dalam manajemen suatu program, dibutuhkan suatu perencanaan yang baik dan perencanaan tersebut haruslah memperhatikan fungsi-fungsi manajemen yang biasa disebut Planning, Organizing, Leading dan Controlling (POLC). Keempat fungsi manajemen ini sangatlah penting dan harus selalu ada dalam praktek manajemen. Peniadaan salah satu dari fungsi manajemen ini akan menjadikan manajemen tidak akan berjalan sesuai dengan harapan dan fungsinya. Dari pengertian di atas terdapat tiga dimensi yang sangat penting, yang pertama yaitu manajemen terjadi berkat kegiatan yang dilakukan oleh seorang pengelola, yang kedua, kegiatan dilakukan secara bersama-sama melalui orang lain untuk mencapai tujuan dan yang ketiga adalah manajemen itu dilaksanakan dalam organisasi sehingga tujuan yang ingin dicapai adalah tujuan organisasi.

Secara umum, pengertian manajemen adalah pengelolaan suatu pekerjaan untuk memperoleh hasil dalam rangka mencapai tujuan yang telah ditentukan dengan cara menggerakkan orang lain untuk bekerja. Maka dari pengertian di atas, dapat disimpulkan bahwa manajemen dalam program televisi sangat berpengaruh pada keberhasilan sebuah acara televisi yang akan diproduksi.

Program acara televisi juga menentukan siapa target yang akan menonton acara televisi tersebut dan bagaimana cara menyajikannya agar dapat diterima dan dinikmati oleh penonton yang menjadi target acara tersebut.Sistem manajemen program pendidikan di TVRI Stasiun Riau \& Kepri sejauh ini sudah cukup memenuhi kriteria-kriteria dasar sebuah manajemen. Seluruh komponen yang bekerja dalam fungsi manajemenen sudah berjalan meski memang masih terdapat beberapa hal yang perlu dibenahi.

Fungsi prerencanaan yang diterapkan manajemen program pendidikan di TVRI stasiun Riau \& Kepri telah mencakup langkah-langkah fungsi perencanaan yang ada hanya saja saat implementasi perlu dilakukan terus menerus sehingga setiap program pendidikan yang di produksi memiliki perencanaan yang matang. Sedangkan pada fungsi penggorganisasian juga berjalan walaupun terkadang mengalami kendala yang dikarenakan oleh terbatasnya sumber daya manusia (SDM), namun masih bisa ditangani dengan baik oleh kerja sama tim. Sejalan dengan itu fungsi pengkoordinasian dalam manajemen program pendidikan di TVRI stasiun Riau \& Kepri juga berjalan berdasarakn aspek pengkoordinasian dalam fungsi manajemen sehingga hubungan yang dibangun secara professional antara pimpinan dan bawahan dengan memberikan kebebasan berkreativitas dalam bekerja, dan juga dibangun dengan rasa kekeluargaan. Dimana pemimpin tidak hanya menuntut hasil maksimal tetapi juga memfasilitasi beberapa kebutuhan tim. Fungsi manajemen yang terakhir yaitu pengawasan, dalam fungsi inilah ketiga fungsi yaitu perencanaan, pengorganisasia, dan pengkoordinasian dievaluasi apakah sudah berjalan sesuai dengan fungsi manajemen yang ada.

Secara keseluruhan upaya-upaya yang dilakukan oleh manajemen TVRI Stasiun Riau \& Kepri dalam hal menghasilkan program pendidikan yang berkualitas yang bukan hanya sekedar menjadi tontonan tetapi juga tuntunan sudah berjalan cukup baik dan sudah mengarah pada standar-standar dasar fungsi manajemen yang ada. Tetapi perlu ditingkatkan terlebih pada peningkatan kinerja saat pengimplementasian fungsi manajemen dilakukan.

Terkait dengan kesimpulan di atas, maka penulis menyarankan sebagai berikut: Dalam memproduksi sebuah program pendidikan yang berkualitas agar produser dam tim manajemen membuat perencanaan yang matang dan berbeda dari program-program yang ada sebelumnya, menempatkan orang yang tepat di posisi yang tepat dan sesuai dengan skill yang dimiliki, untuk meminimalisir kesalahan yang terjadi, dan agar sasaran yang ingin dicapai dapat selesai dengan baik. Untuk 


\section{JURNAL \\ MANAJEMEN PENDIDIKAN}

PENELITIAN KUALITATIF
Vol. 5 No.2 Maret 2021: pp.67-73 e-ISSN: 2775-6904 | p-ISSN: 2502-9487

peningkatan sumber daya manusia yang ada agar manajemen memeberikan pembekalan dan pelatihan yang rutin, agar para karyawan selalu dapat memperbarui kempauan dan menjadi tim yang lebih kretatif dan produktif, Sebagai seorang pemipin yang mengarahkan dan berkoordinasi dengan karyawan dalam manajemen, produser selalu memahami kondisi keraj dan selalu menciptakan situasi kerja yang nyaman, sehingga iklim kerja yang baik diharapkan dapat menghasilkan program-program pendidikan yang berkualitas.Dalam hal pengawasan agar manajemen selalu melakukan pengawasan rutin.

\section{DAFTAR PUSTAKA}

Ashadi Siregar, 2001. Menyingkap Media Penyiaran: Membaca Televisi Melihat Radio. Jakarta: Kencana

Maleong LJ, 1989. Metode Penelitian Kualitatif. Bandung: Remaja Rosda Karya.

Miles, B. Mathew dan Michael Huberman. 1992. Analisis Data Kualitatif Buku

Sumber Tentang Metode-metode Baru. Jakarta: UIP.

Morissan, 2008. Manajemen Media Penyiaran. Jakarta: Kencana.

Undang-Undang No. 20 tahun 2003, Tentang Pendidikan Nasional 